\title{
BIODIVERSITY OF THE ARCTIC OCEAN IN THE FACE OF CLIMATE CHANGE
}

\author{
JAN MARCIN WĘSŁAWSKI \\ Institute of Oceanology, Polish Academy of Sciences \\ Powstańców Warszawy 55, 81-712 Sopot, Poland \\ e-mail: weslaw@iopan.gda.pl
}

\begin{abstract}
Global climate changes which has been observed over the recent years affects organisms occurring in the Arctic seas and the functioning of the whole maritime ecosystems there. The research note presents and briefly analyses the biological diversity of the Arctic Ocean and the most important factors which change the relations between organisms and the environment in the Arctic.
\end{abstract}

KEY WORDS: Arctic, biodiversity, climate change.

Various scenarios of global change shown by IPCC and by a regional publication relating to the Arctic (ACIA 2005) in unison demonstrate that the biggest intensiveness of warming is already observed in the Arctic, especially in the area of Beaufort Sea and in the European Arctic. For organisms occurring in the Arctic seas and for the functioning of the whole maritime ecosystems there are three factors that are the most important:

- thinning of the ice cover and lessening of the area which it takes;

- a rise of sea water temperature;

- an increase in the meltwater outflow from the (glacial) land causing a lowering of salinity level.

Each of the above factors has a number of consequences which change the relations between organisms and the environment, e.g. a thinner, intersected with numerous canals drifting ice cover is favourable for the development of heliophilous 
species of microplankton which replace the so far dominant species adapted to a low intensity of light. This change of organisms is not limited only to a change of species, but most of all means replacing big, slowly growing and rich in high energy polyunsaturated fatty acids (PUFA) diatoms by small, fast growing algae of Prymnesiophycae group and other taxa opportunistic to environmental conditions. As a result, the basis of the trophic web of the Arctic Ocean change towards a more and more developed microbial loop and towards worse and worse feeding conditions for big species of herbivorous zooplankton and, as a consequence, for fish, birds and sea mammals. It does not mean 'a catastrophe' but a change of a unique ecological system of low diversity and very high effectiveness of energy flow to big animals into a system of a subarctic-boreal character, where the biggest role in the water depths is played by microorganisms and the biggest beneficiary of primary production are pelagic fish (capelins, herrings, sprats, mackerels). The chain of consequences described above is regarded by a part of the milieu of Arctic countries as a desired one, since it may open up new, much richer fisheries in the part of the Arctic freed of ice (ACIA 2005). Unfortunately, complex phenomena based on multispecies relations in an ecosystem do not always proceed in a predictable way. The scenario of intense development of the microbial loop is equally probable. Possible are blooms of flagellate, bacteria and cyanobacteria, which lead to using organic carbon from primary production within the microbial loop and to worsening of food conditions for fish as well.

Understanding a possible reaction of the sea ecosystem of the Arctic must be based on the knowledge of biological diversity - to be able, among other things, to predict the potential of replacing some species with others and to know which functions - processes in the ecosystem are controlled by single species. In such cases a loss of one species (or a significant drop in its number) causes an incommensurably big effect on the whole system. An example of such crucial species in the pelagic Arctic is Boreogadus saida, a small, adapted to sea ice fish, which is the main food source of all sea birds nesting in large numbers, ringed and harp seals and, to a large extent, of Beluga whales, minky whales and narwhals.

The ten-year-long global programme Census of Marine Life finished in 2010 included an Arctic project called ArcOD (Arctic Ocean Diversity), which aimed at estimating the biological diversity of the pelagic Arctic. The research conducted by teams from over ten countries (including the Institute of Oceanology PAS) allowed to make a synthesis of knowledge acquired so far. The most important conclusion was confirming the previous suppositions that the Arctic is one of the sea regions with the most limited number of species - the number of Eucariota species is about 8000 , the number of species still to be discovered in this region predicted by statistical models is the same - so we may assume that we have so far discovered about half of the Arctic species. In comparison with the Mediterranean Sea or tropical areas, where the numbers of the known species are between 25000 and 50000 , this is not many. The number of endemic species is also very low - it is 
an effect of the short time which has passed since today's Arctic ecosystem formed - about 0,7 million years. A vast majority of modern Arctic fauna are species coming from the Atlantic with a small addition of the fauna from the Pacific Ocean. The analysis of occurrence of the Arctic shelf fauna clearly shows a trend in which the further from the source (the Atlantic waters), the sparser the fauna - so the richest is Barents Sea, supplied directly by North Atlantic Stream, and towards east the number of species drops, to the record small one in the shallow, characterised by low salinity level Laptev Sea.

The estimations above are based on materials gathered in a nonuniform way the largest data base of the distribution of the sea fauna OBIS (Ocean Biogeographic Information System) shows that shelf areas, used by fishing industry, are ones of the best known in the world, while only a few percent of the deep sea below 1000 $\mathrm{m}$ is examined. A special case is Lincoln Sea, extending in north of Greenland to the west, a large area covered with pack ice, where only a few samples of fauna have been collected from so far.

A set of studies on the changes observed in the biodiversity of the Arctic was published in the special issues of Marine Biodiversity and Progress in Oceanography magazines in 2011, an overview of the subject can be found in the article by Blum et al. (2011).

In the planned research of the Arctic's biodiversity an important role is played by the Polish Arctic Station in Hornsund on Spitsbergen, where one of the key points for the research of ATBI (all taxa biodiversity inventory) areas is localized; the data are regularly published at the widely available website and the number of species found in this area reaches 1400 .

\section{REFERENCES}

ACIA, 2005, Arctic Climate Impact Assessment, Cambridge University Press, Cambridge, $1042 \mathrm{pp}$.

ARCOD - http://www.arcodiv.org/

ATBI - http://www.iopan.gda.pl/projects/biodaff/

Blum B., Gebruk A., Gradinger R., Hopcroft RR., Huettmann F., Kosobokova K., Sicienko B., Węsławski J.M., 2011, Arctic Marine Biodiversity an update of species richness and examples of biodiversity change, Oceanography, 24, 198-214.

IPCC - http://www.ipcc.ch/

OBIS - http://www.iobis.org/ 